\title{
PENGARUH AKTIFITAS KENDARAAN BERMOTOR TERHADAP KEBISINGAN DI KAWASAN PERTOKOAN COYUDAN SURAKARTA
}

\author{
Dyah Ratri Nurmaningsih ${ }^{1}$, Kusmiyati ${ }^{2}$, Agus Riyanto $\mathbf{S R}^{3}$ \\ ${ }^{1}$ Program Studi Teknik Lingkungan, Fakultas Sains dan Teknologi, UIN Sunan Ampel Surabaya \\ ${ }^{2}$ Jurusan Teknik Kimia, Fakultas Teknik, Universitas Muhammadiyah Surakarta \\ ${ }^{3}$ Jurusan Teknik Sipil, Fakultas Teknik, Universitas Muhammadiyah Surakarta
}

\begin{abstract}
ABSTRAK
Semakin pesatnya aktivitas transportasi khususnya kendaraan bermotor berdampak meningkatnya intensitas polusi suara berupa kebisingan bagi lingkungan disekitar jalan tersebut. Kawasan pertokoan Coyudan Surakarta diambil sebagai objek penelitian karena kawasan tersebut terletak pada kawasan bisnis kota Surakarta atau CBD (Central Bussiness Distric) dan juga kawasan akses lalu lintas perkotaan Surakarta yang cukup padat. Metode yang digunakan dalam penelitian ini adalah metode survey (dengan menggunakan alat) dan metode analisa pendekatan (dengan menggunakan rumus empiris). Hasil dari penelitian ini menunjukkan bahwa besar nilai tingkat kebisingan telah melampaui baku mutu yang diijinkan, yaitu $70 \mathrm{~dB}(\mathrm{~A})$ untuk kawasan perdagangan dan jasa. Penanganan/ alternatif solusi dari penelitian ini dilakukan sesuai keadaan karakteristik lokasi yang diteliti : penanaman pohon-pohon kecil di pinggir ruas jalan dengan menggunakan media pot, hal ini disebabkan oleh pada daerah ini sudah tertutup paving. Pohon-pohon yang dapat dimanfaatkan antara lain: palem botol, lidah mertua, bambu-bambuan, kemuning, dll, dan juga penggunaan bahan penyerap suara (seperti permadani) pada dinding dan lantai.
\end{abstract}

Kata kunci: lalu lintas, $C B D$ dan kebisingan

\section{PENDAHULUAN}

\section{Latar belakang masalah}

Indonesia merupakan negara yang sedang berkembang dengan pembangunan yang sangat pesat, hal ini dapat dilihat dari perkembangan ekonominya yang cukup pesat. Akibat dari perkembangan ekonomi tersebut serta jumlah penduduk yang cukup besar, maka berkembang pula aktivitas dan kegiatan masyarakat di segala bidang sehingga membutuhkan sarana penunjang yang memadai, dimana semua itu memerlukan sarana transportasi untuk memperlancar kegiatan dan aktivitas tersebut sekaligus merupakan salah satu penunjang perkembangan suatu wilayah (Astaleni, 2002). Begitu juga dengan kota Surakarta yang merupakan salah satu wilayah perkotaan di Indonesia yang terletak di Provinsi Jawa Tengah yang saat ini sedang berkembang, baik dalam bidang industri, jasa, permukiman, pendidikan, perdagangan maupun transportasi (Kadyarsi, 2006). Perkembangan jumlah dan macam sarana transportasi pada jalan raya tersebut tentunya mempunyai dampak pada lingkungan di sepanjang jalan tersebut. Dampak yang terjadi salah satunya adalah meningkatnya intensitas polusi suara berupa kebisingan bagi lingkungan disekitar jalan tersebut (Setiawan et all, 2002).

Bising adalah bunyi yang tidak dikehendaki yang dapat mengganggu dan atau membahayakan kesehatan. Lalu lintas merupakan salah satu sumber kebisingan yang mengganggu sebagian besar masyarakat perkotaan (Poernomosidhi, 1995). Salah satu sumber bising lalu lintas jalan antara lain berasal dari kendaraan bermotor, baik roda dua, tiga maupun roda empat, dengan sumber penyebab bising yaitu bunyi klakson saat kendaraan ingin mendahului atau minta jalan. Gesekan mekanis antara ban dengan badan jalan pada saat pengereman mendadak dan kecepatan tinggi; suara knalpot akibat penekanan pedal gas secara berlebihan atau knalpot imitasi; tabrakan antara sesama kendaraan; pengecekan pengapian di bengkel pemeliharaan; dan frekuensi mobilitas kendaraan, baik dalam jumlah maupun kecepatan (Depkes, 1995 seperti dalam kutipan Ikron et all, 2005).

Dalam perencanaan transportasi jalan perlu dikaji mengenai tingkat kebisingan dan emisi gas buang akibat volume lalu lintas terhadap lingkungan di sekitar jalan tersebut (Purwandi, 2006). Dalam penelitian ini penulis mengambil kawasan pertokoan Coyudan Surakarta sebagai obyek penelitian mengenai seberapa besar tingkat kebisingan dan emisi gas yang terjadi. 
Begitu juga dengan kawasan pertokoan Coyudan yang merupakan kawasan strategis sebagai pusat kegiatan perdagangan atau bisnis utama (Central Bussiness Distric) di Kota Surakarta, sehingga mengakibatkan tingginya volume lalu lintas pada kawasan tersebut. (Wahyudi, 2002). Tingginya volume lalu lintas menyebabkan dampak negatif seperti kebisingan lalu lintas yang pada akhirnya dapat mengganggu kegiatan jual beli, disamping itu juga dapat mengganggu kesehatan. Kondisi lalu lintas pada kawasan pertokoan Coyudan dapat dilihat pada Gambar 1. di bawah ini.

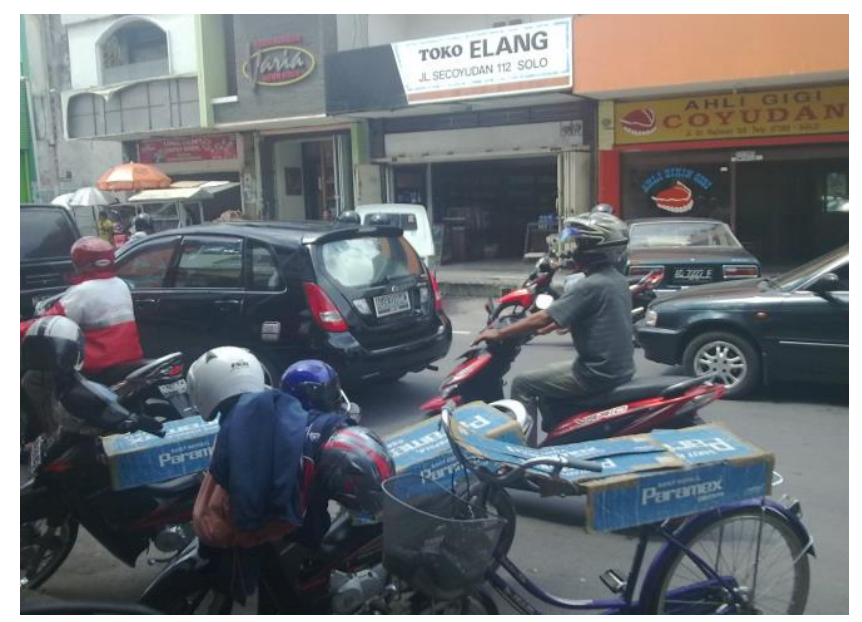

Gambar 1. Kondisi lalu lintas kawasan pertokoan Coyudan

Dengan adanya uraian yang telah dijelaskan sebelumnya, penulis menganggap perlu diadakannya penelitian mengenai tingkat kebisingan yang disebabkan oleh arus lalu lintas yang melewati kawasan tersebut. Hasil dari penelitian diharapkan bisa meminimalisir permasalahan tersebut, sekaligus mencari alternatif solusinya.

\section{Maksud dan tujuan}

Mengetahui besar nilai kebisingan yang terjadi akibat lalu lintas di kawasan pertokoan Coyudan Surakarta, usaha penanganan yang sesuai dengan permasalahan dan karakter daerah tersebut serta sebagai bahan pertimbangan bagi pengambil kebijakan dalam hubungannya dengan perencanaan transportasi atau perancang bangunan agar dapat lebih memperhatikan kondisi lingkungan yang ada. mencari alternatif solusinya.

\section{Lokasi dan waktu penelitian}

Penelitian ini dilakukan di kawasan pertokoan Coyudan Surakarta, dengan pertimbangan karena kawasan ini termasuk sebagai salah satu pusat kegiatan perdagangan utama atau CBD (Central Bussiness Distric) di Surakarta dan sebagai akses lalu lintas yang strategis dan padat. Setelah dilakukan survey pendahuluan terhadap lalu lintas yang ada di kawasan ini, maka pengukuran kebisingan dan pengambilan data lalu lintas dilakukan selama 3 jam antara pukul 11.00 - 14.00 BBWI yang dinyatakan sebagai waktu terpadat dalam satu hari. Dan hari pelaksanaan yaitu pada hari Senin dan Rabu untuk mewakili keadaan lalu lintas dalam satu minggu.

\section{METODOLOGI PENELITIAN}

Metodologi yang digunakan dalam pelaksanaan penelitian ini dimulai dari studi pustaka, metode survey awal untuk penentuan lokasi dan waktu penelitian, survey lanjutan untuk perolehan data, kemudian metode analisa dengan menggunakan alat dan metode analisa pendekatan (dengan menggunakan rumus empiris). Hasil analisa kemudian di bandingkan dengan Tabel 1. Baku Tingkat Kebisingan, apakah memenuhi baku mutu kebisingan yang ditetapkan atau tidak. 
Tabel 1. Baku tingkat kebisingan

\begin{tabular}{clc}
\hline No. & Peruntukan kawasan/lingkungan kegiatan & Tingkat kebisingan dB(A) \\
\hline 1. & Perumahan dan pemukiman & 55 \\
\hline 2. & Perdagangan dan jasa & 70 \\
\hline 3. & Perkantoran dan perdagangan & 65 \\
\hline 4. & Ruang terbuka hijau & 50 \\
\hline 5. & Industri & 70 \\
\hline 6. & Pemerintah dan fasilitas umum & 60 \\
\hline 7. & Rekreasi & 70 \\
\hline 8. & Bandar Udara, Stasiun kereta api, Pelabuhan laut & 70 \\
\hline 9. & Cagar budaya & 60 \\
\hline 10. & Rumah sakit dan sejenisnya & 55 \\
\hline 11. & Sekolah atau sejenisnya & 55 \\
\hline 12. & Tempat ibadah atau sejenisnya & 55 \\
\hline Sumber: Keputusan Menteri Lingkungan Hidup Kep-48/MENLH/1996, 25 November 1996)
\end{tabular}

\section{ANALISIS, HASIL DAN PEMBAHASAN}

\section{Analisis kebisingan secara rumus empiris}

Perhitungan tingkat kebisingan berdasarkan rumus empiris menggunakan data volume lalu lintas (Q), kecepatan rata-rata kendaraan $(\mathrm{V})$, prosentase kendaraan berat $(\mathrm{p})$ dan gradien jalan $(\mathrm{G})$. Contoh perhitungan diambil pada waktu jam puncak pada salah satu titik kajian yang diteliti yaitu kawasan pendidikan Sekolah Menengah Pertama Pangudi Luhur Bintang Laut Surakarta pada hari Senin, 25 Januari 2010 pukul 11.00-14.00 BBWI, sebagai berikut :

- Volume jam puncak (Q) : $4919 \mathrm{kend} / \mathrm{jam}$

- Kecepatan rata-rata (V)

- Jarak titik kajian/1/2 Lebar jalan

- Gradien jalan

- Persentase kendaraan berat pada jam puncak (p)

Analisa :

a. Basic Noise Level (BNL)

$$
\begin{aligned}
\mathrm{L}_{10} & =42,2+10 \log \mathrm{Q} \mathrm{dB}(\mathrm{A}) \\
& =42,2+10 \log 4919 \mathrm{~dB}(\mathrm{~A}) \\
\mathrm{L}_{10} & =79,12 \mathrm{~dB}(\mathrm{~A})
\end{aligned}
$$

b. Koreksi terhadap kecepatan rata-rata kendaraan berat

$$
\begin{aligned}
& C_{1}=33 \log \left(V+40+\frac{500}{V}\right)+10 \log \left(1+\frac{5 p}{V}\right)-68,8 d B(A) \\
& C_{1}=33 \log \left(32,99+40+\frac{500}{32,99}\right)+10 \log \left(1+\frac{5.0,53}{32,99}\right)-68,8 d B(A) \\
& C_{1}=-4,27 \mathrm{~dB}(\mathrm{~A})
\end{aligned}
$$

c. Koreksi terhadap gradien

$$
\begin{aligned}
\mathrm{C}_{2} & =0,3 \cdot \mathrm{G} \mathrm{dB}(\mathrm{A}) \\
& =0,3 \cdot 2 \mathrm{~dB}(\mathrm{~A}) \\
\mathrm{C}_{2} & =0,6 \mathrm{~dB}(\mathrm{~A})
\end{aligned}
$$

d. Koreksi terhadap kondisi antara sumber bunyi dengan penerima (termasuk dalam lebih besar 50\% diperkeras atau tidak menyerap bunyi)

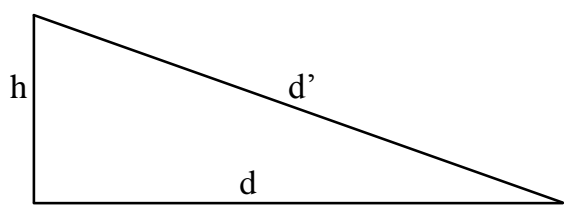

dengan $\mathrm{h}=$ ketinggian titik penerima dari muka tanah, $\mathrm{d}^{\prime}=$ panjang garis pandangan dari sumber bunyi ke penerima, $\mathrm{d}=$ jarak sumber bunyi dengan penerima 
Lokasi : dekat jalan

$$
\begin{aligned}
\mathrm{h} & =1,5 \mathrm{~m} \\
\mathrm{~d} & =8,5 \mathrm{~m} \\
\mathrm{~d}^{\prime} & =\sqrt{1,5^{2}+8,5^{2}}=8,63 \mathrm{~m} \\
\mathrm{C}_{3} & =-10 \log \left(\mathrm{d}^{\prime} / 13,5\right) \mathrm{dB}(\mathrm{A}) \\
& =-10 \log (8,63 / 13,5) \mathrm{dB}(\mathrm{A}) \\
\mathrm{C}_{3} & =1,95 \mathrm{~dB}(\mathrm{~A})
\end{aligned}
$$

\begin{tabular}{|c|c|c|c|c|c|}
\hline \multirow{2}{*}{ Waktu } & $\frac{B N L\left(\mathrm{~L}_{10}\right)}{\mathrm{dB}(\mathrm{A})}$ & $\frac{C_{1}}{d B(A)}$ & $\begin{array}{c}C_{2} \\
d B(A)\end{array}$ & $\frac{C_{3}}{d B(A)}$ & $\begin{array}{c}P N L \\
\operatorname{dB}(\mathrm{A})\end{array}$ \\
\hline & (5) & (6) & (7) & (8) & $(5)+(6)+(7)+(8)$ \\
\hline $11: 00-12: 00$ & 74,74 & $-5,07$ & 0,6 & 3,39 & 73,66 \\
\hline $11: 15-12: 15$ & 74,73 & $-5,07$ & 0,6 & 3,39 & 73,65 \\
\hline $11: 30-12: 30$ & 74,70 & $-5,02$ & 0,6 & 3,39 & 73,67 \\
\hline $11: 45-12: 45$ & 74,92 & $-4,98$ & 0,6 & 3,39 & 73,93 \\
\hline $12: 00-13: 00$ & 75,10 & $-4,98$ & 0,6 & 3,39 & 74,10 \\
\hline $12: 15-13: 15$ & 75,36 & $-4,95$ & 0,6 & 3,39 & 74,40 \\
\hline $12: 30-13: 30$ & 75,44 & $-4,91$ & 0,6 & 3,39 & 74,52 \\
\hline $12: 45-13: 45$ & 75,33 & $-4,95$ & 0,6 & 3,39 & 74,37 \\
\hline $13: 00-14: 00$ & 75,05 & $-4,98$ & 0,6 & 3,39 & 74,06 \\
\hline Rata-rata PNL & & & & & 74,04 \\
\hline Berdasarkan baku & at kebisingar & bel 1) & & & $>70$ \\
\hline Kriteria & & & & & tidak aman \\
\hline
\end{tabular}

e. Predicted Noise Level (PNL)

$$
\begin{aligned}
P N L & =B N L+\mathrm{C}_{1}+\mathrm{C}_{2}+\mathrm{C}_{3} \\
& =79,12+(-4,27)+0,6+1,95 \\
P N L & =77,39 \mathrm{~dB}(\mathrm{~A})
\end{aligned}
$$

\begin{tabular}{|c|c|c|c|c|c|}
\hline \multirow[t]{2}{*}{ Waktu } & $\begin{array}{c}B N L\left(\mathrm{~L}_{10}\right) \\
\operatorname{dB}(\mathrm{A})\end{array}$ & $\begin{array}{c}C_{1} \\
d B(A)\end{array}$ & $\begin{array}{c}\mathrm{C}_{2} \\
\mathrm{~dB}(\mathrm{~A})\end{array}$ & $\begin{array}{c}\mathrm{C}_{3} \\
\mathrm{~dB}(\mathrm{~A})\end{array}$ & $\begin{array}{c}\text { PNL } \\
\mathrm{dB}(\mathrm{A}) \\
\end{array}$ \\
\hline & (5) & (6) & (7) & (8) & $(5)+(6)+(7)+(8)$ \\
\hline $11: 00-12: 00$ & 74,56 & $-4,90$ & 0,6 & 3,39 & 73,65 \\
\hline $11: 15-12: 15$ & 74,66 & $-4,96$ & 0,6 & 3,39 & 73,70 \\
\hline $11: 30-12: 30$ & 74,66 & $-5,01$ & 0,6 & 3,39 & 73,64 \\
\hline $11: 45-12: 45$ & 74,97 & $-4,98$ & 0,6 & 3,39 & 73,98 \\
\hline $12: 00-13: 00$ & 75,01 & $-5,02$ & 0,6 & 3,39 & 73,98 \\
\hline $12: 15-13: 15$ & 75,09 & $-4,93$ & 0,6 & 3,39 & 74,14 \\
\hline $12: 30-13: 30$ & 75,26 & $-4,90$ & 0,6 & 3,39 & 74,35 \\
\hline $12: 45-13: 45$ & 75,00 & $-4,93$ & 0,6 & 3,39 & 74,06 \\
\hline $13: 00-14: 00$ & 74,96 & $-4,93$ & 0,6 & 3,39 & 74,02 \\
\hline Rata-rata PNL & & & & & 73,95 \\
\hline Berdasarkan baku & at kebisingar & abel 1) & & & $>70$ \\
\hline Kriteria & & & & & tidak aman \\
\hline
\end{tabular}

Menggunakan langkah yang sama dengan perhitungan di atas untuk mencari nilai Predicted Noise Level (PNL) semua titik kajian penelitian dan hasil selengkapnya dapat dilihat pada Tabel 2 dan Tabel 3. berikut ini.

Tabel 2. Analisa tingkat kebisingan kawasan pertokoan Coyudan hari Senin, 25 Januari 2010

Tabel 3. Analisa tingkat kebisingan kawasan pendidikan pertokoan Coyudan hari Rabu, 27 Januari 2010 


\section{Analisis kebisingan secara non empiris}

Data kebisingan diperoleh dari hasil pengukuran dengan alat sound level meter dari Laboratorium Teknik Sipil Jurusan Teknik Sipil Fakultas Teknik Universitas Muhammadiyah Surakarta. Pengukuran dilakukan pada hari Senin dan Rabu pukul 11.00 - 14.00 BBWI. Hasilnya dapat dilihat pada Tabel 3. berikut ini.

Tabel 4. Tingkat kebisingan lalu lintas kawasan pertokoan Coyudan Surakarta

\begin{tabular}{ccc}
\hline Jam & Senin, 25 Januari 2010 & Rabu, 27 Januari 2010 \\
\hline $11: 00-12: 00$ & $\mathbf{d B}(\mathbf{A})$ & $\mathbf{d B}(\mathbf{A})$ \\
\hline $11: 15-12: 15$ & 74,74 & 73,66 \\
\hline $11: 30-12: 30$ & 74,73 & 73,65 \\
\hline $11: 45-12: 45$ & 74,70 & 73,67 \\
\hline $12: 00-13: 00$ & 74,92 & 73,93 \\
\hline $12: 15-13: 15$ & 75,10 & 74,10 \\
\hline $12: 30-13: 30$ & 75,36 & 74,40 \\
\hline $12: 45-13: 45$ & 75,44 & 74,52 \\
\hline $13: 00-14: 00$ & 75,33 & 74,37 \\
\hline $\begin{array}{c}\text { Berdasarkan baku tingkat } \\
\text { kebisingan (Tabel 1) }\end{array}$ & 75,05 & 74,06 \\
\hline Kriteria & $>70$ & $>70$ \\
\hline
\end{tabular}

(Sumber: hasil penelitian Nurmaningsih, 2011)

\section{Pembahasan hasil analisis}

Tingkat kebisingan pada kawasan pertokoan Coyudan dapat dilihat pada Gambar 2. Berdasarkan Gambar 2 dapat diketahui bahwa untuk seluruh lokasi penelitian, nilai intensitas kebisingan yang diperoleh sudah melewati ambang batas/baku mutu yang diijinkan untuk kawasan perdagangan dan jasa yaitu $70 \mathrm{~dB}(\mathrm{~A})$. Grafik nilai besar tingkat kebisingan pada kawasan pertokoan Coyudan dapat dilihat pada Gambar 2 di bawah ini.

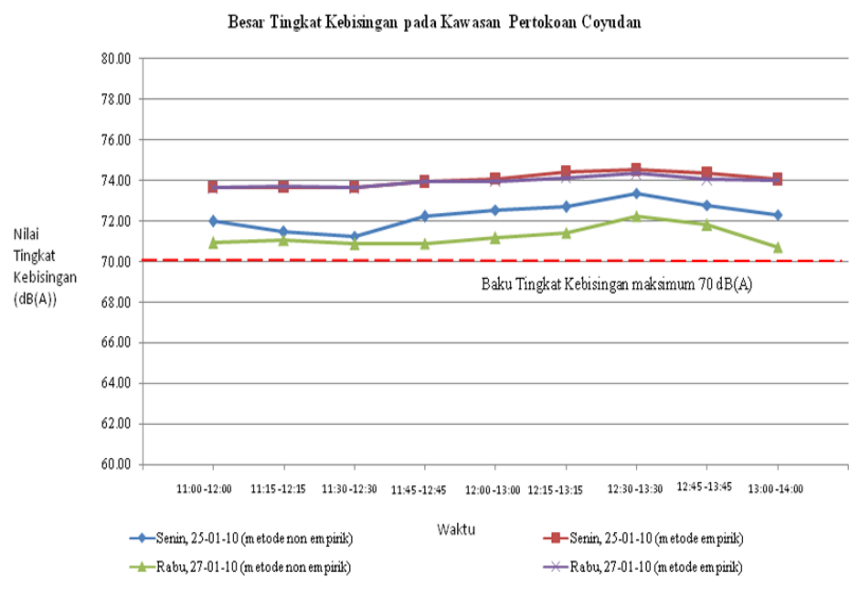

Gambar 2. Besar tingkat kebisingan pada kawasan pertokoan Coyudan

Nilai kebisingan tertinggi pada ruas jalan kawasan pertokoan Coyudan terjadi pada hari Senin, 25 Januari 2010 pukul 12:30-13:30 yaitu sebesar 74,52 $\mathrm{dB}(\mathrm{A})$. Hal ini dikarenakan pada jam tersebut banyak masyarakat yang datang ataupun pulang untuk/ setelah melakukan kegiatan ekonomi, disamping itu karena ruas jalan Secoyudan merupakan akses jalan yang selalu padat lalu lintas. Dari gambar di atas juga dapat dilihat bahwa hasil penelitian baik dengan menggunakan metode empiris menghasilkan nilai yang tidak terlampau jauh jika dibandingkan dengan metode non empiris, sehingga perhitungan intensitas kebisingan rumus empiris masih bisa dipertanggungjawabkan. 


\section{Pembahasan alternatif solusi}

Dari pembahasan di atas diketahui bahwa nilai kebisingan telah melampaui baku mutu yang diijinkan, sehingga diperlukan penanganan yang sesuai dengan keadaan lingkungan lokasi penelitian. Sedangkan untuk mengurangi kebisingan pada kawasan pertokoan Coyudan dapat dilakukan penanaman pohon-pohon kecil di pinggir ruas jalan dengan menggunakan media pot, hal ini karena pada daerah ini sudah tertutup paving. Menurut Werdiningsih (2007) pohon-pohon yang dapat dimanfaatkan antara lain: palem botol, lidah mertua, bambu-bambuan, kemuning dan lainlainnya. Disamping itu juga penggunaan bahan penyerap suara (seperti permadani) pada dinding dan lantai, sehingga diharapkan dapat mengurangi bunyi dan gaung akibat geseran ataupun getaran-getaran suara keras lainnya (Handoko, 2010). Selain itu, pengurangan kebisingan juga dapat dilakukan dengan pelarangan pemakaian mobil atau motor dengan knalpot terbuka, perbaikan kualitas sarana transportasi umum sehingga pemilihan transportasi umum akan menjadi pilihan utama dalam melakukan aktifitas sehari-hari, mensosialisasikan budaya berjalan dan bersepeda untuk tujuan perjalanan yang dekat.

\section{KESIMPULAN}

Besar nilai tingkat kebisingan tertinggi di kawasan pertokoan Coyudan Surakarta terjadi pada pukul 12:30-13:30. Dari hasil penelitian dengan menggunakan metode empiris menghasilkan nilai yang tidak terlampau jauh jika dibandingkan dengan metode non empiris, sehingga perhitungan dengan menggunakan metode empiris masih dapat dipertanggungjawabkan.

1. Besar nilai tingkat kebisingan tertinggi akibat arus lalu lintas berdasarkan pendekatan empiris untuk kawasan Pertokoan Coyudan Surakarta adalah 74,52 dB(A), batas besar tingkat kebisingan menurut Keputusan Menteri Negara Lingkungan Hidup Kep-48/MENLH/1996 25 November 1996 untuk kawasan perdagangan dan jasa adalah sebesar $70 \mathrm{~dB}(\mathrm{~A})$, sehingga tingkat kebisingan sudah melebihi baku mutu yang ditetapkan.

2. Besar nilai tingkat kebisingan tertinggi akibat arus lalu lintas berdasarkan data di lapangan (pengukuran dengan menggunakan alat) untuk kawasan pertokoan Coyudan Surakarta adalah 73,37 dB(A), batas besar tingkat kebisingan menurut Keputusan Menteri Negara Lingkungan Hidup Kep-48/MENLH/1996 25 November 1996 untuk kawasan perdagangan dan jasa adalah sebesar $70 \mathrm{~dB}(\mathrm{~A})$, sehingga tingkat kebisingan sudah melebihi baku mutu yang ditetapkan.

Pengurangan kebisingan dapat dilakukan dengan pelarangan pemakaian mobil atau motor dengan knalpot terbuka, perbaikan kualitas sarana transportasi umum sehingga pemilihan transportasi umum akan menjadi pilihan utama dalam melakukan aktifitas sehari-hari, mensosialisasikan budaya berjalan dan bersepeda untuk tujuan perjalanan yang dekat. Adapun penanganan yang dilakukan dengan melihat keadaan lingkungan disekitar lokasi penelitian, yaitu: dipertanggungjawabkan.

1. Penanaman pohon-pohon kecil di pinggir ruas jalan dengan menggunakan media pot hal ini karena pada daerah ini sudah tertutup paving. Pohon-pohon yang dapat dimanfaatkan antara lain: palem botol, lidah mertua, bambu-bambuan, kemuning dan lain-lainnya.

2. Penggunaan bahan penyerap suara (seperti permadani) pada dinding dan lantai.

\section{DAFTAR PUSTAKA}

Anonim, 1996, Baku Tingkat Kebisingan Menteri Negara Lingkungan Hidup, Nomor : Kep48/MENLH/II/1996/25/Nopember1996, Jakarta.

Anonim, 1997, Manual Kapasitas Jalan Indonesia, Directorat Jenderal Bina Marga.

Anonim, 1997, Perencanaan Transportasi, Universitas Guna Dharma Jakarta, Jakarta.

Anonim, 2004, Panduan Membaca Peta Rupabumi Indonesia, Pusat Pelayanan Jasa dan Informasi, Bakosurtanal, Cibinong. Didownload : http://eksan.komite-sman2bjb.web.id/wp-content/uploads/2008/04/panduanmembaca-peta.pdf

Astaleni, Siti Nuryanti, 2002, Studi Analisa Tingkat Kebisingan Akibat Lalulintas Serta Dampaknya Terhadap Lingkungan, Universitas Gunadharma.

Buchari, 2007, Kebisingan Industri dan Hearing Conservation Program, Universitas Sumatera Utara, Medan. usu repository Didownload: http://repository.usu.ac.id/bitstream/123456789/1435/1/07002749.pdf

Handoko, Sungging, 2010, Kebisingan dan Pengaruhnya pada Lingkungan Hidup. EDUCARE: Jurnal Pendidikan dan Budaya. Didownload: http://educare.e-fkipunla.net/index2.php?option=com_content\&do_pdf=1\&id=56

Hidayati, N., 2007, Pengaruh Arus Lalu Lintas terhadap Kebisingan (Studi Kasus Beberapa Zona Pendidikan di Surakarta), Staf pengajar jurusan Teknik Sipil - Universitas Muhammadiyah SurakartaJurnal Dinamika Teknik Sipil Vol 7, Januari 2007 45:54.

Hobbs, F. D., 1995, Perencanaan dan Teknik Lalulintas I, Fakultas Teknik Universitas Gadjah Mada, Yogyakarta. 
Ikron, Djaja, I. M., \& Wulandari, R. A., 2005, Pengaruh Kebisingan Lalulintas Jalan Terhadap Gangguan Kesehatan Psikologis Anak SDN Cipinang Muara Kecamatan Jatinegara, Kota Jakarta Timur, Propinsi DKI Jakarta, Departemen Kesehatan Lingkungan, Fakultas Kesehatan Masyarakat, Universitas Indonesia.

Masnur, S. I., 2008, Evaluasi Peruntukan Lahan Setelah Pelebaran Jalan (Studi Kasus Kecamatan Medan Sunggal), Sekolah Pasca Sarjana, Universitas Sumarta Utara, Medan.

Miro, F., 2005, Perencanaan Transportasi, Universitas Gadjah Mada, Yogyakarta.

Mulyono, S. G., 2005, Analisa Kebisingan Akibat Arus Lalulintas Di Beberapa Rumah Sakit Di Kota Surakarta, Fakultas Teknik Universitas Muhammadiyah Surakarta.

Nurmaningsih, D. R., 2011, Analisis Tingkat Kebisingan Dan Emisi Gas Buang Secara Empiris Dan Non Empiris Serta Alternatif Solusinya (Studi Kasus Kawasan Pendidikan Sekolah Menengah Pertama Pangudi Luhur Bintang Laut Surakarta Dan Kawasan Pertokoan Coyudan), Universitas Muhammadiyah Surakarta.

Pariyanto, A., 2005, Prediksi Tingkat Kebisingan dan Emisi Gas Buang Kendaraan pada Jalan Jenderal Sudirman - Sukoharjo, Universitas Muhammadiyah Surakarta.

Pudjowati, U. R., 2008, Efiktivitas Peredaman Kebisingan Kendaraan Bermotor Dengan Menggunakan Vegetasi Di Jalan Tol Waru - Sidoarjo, Program Pascasarjana Universitas Brawijaya.

Poernomosidhi, P.I.F. (1995). "Review on Road Environment Condition and Research on Traffic Noise and Air Pollution in Indonesia", Paper for the Technical Visit to Public Work Research Institute, Tsukuba, Japan, 25th Sept.- 6th Oct. 1995.

Purwandi, J., 2006, Analisis Tingkat Kebisingan Dan Emisi Gas Buang Di Jalan Slamet Riyadi Dan Alternatif Solusinya (Kajian Empirikal Dan Non Empirikal), Tesis Magister Teknik Sipil Universitas Muhammadiyah Surakarta.

Puspita, R. D., 2005, Pengaruh Tingkat Kebisingan Akibat Lalulintas Terhadap Konsentrasi Belajar Mengajar Di Sekolah Serta Dampak Emisi Gas Buang Yang Ditimbulkan Bagi Kesehatan ( Studi Kasus SDN Kleco II dan SMP Muhammadiyah 5 Surakarta), Universitas Muhammadiyah Surakarta.

Santoso, G. D., 2006, Analisis Tingkat Kebisingan Dan Emisi Gas Buang Akibat Lalulintas Serta implikasinya Terhadap Karakteristik Tata Guna Lahan (Studi Kasus Ruas Jalan Raya Sukowati Km. 0+ 000 - Km. 5+000 DenganTitik Tinjauan Km. O+000 Dari Pusat Kota Sragen), Tesis Magister Teknik Sipil Program Pasca Sarjana, Universitas Muhammadiyah Surakarta

Setiawan, R., Arief, T. D., Handayani, N., \& Sawitri, P., 2002, Analisa Tingkat Kebisingan Laulintas Pada Jalan Tol Ruas Waru - Sidoarjo, Jurusan Teknik Sipil, Fakultas Teknik Sipil Dan Perencanaan, Universitas Kristen Petra, Surabaya.

Soehodho, S., \& Taufick, E. S., 2005, Study On Correlation Between motor Vichle Emmision And Public Health, Professor of Center for Transport Studies Department of Environmental Science, University of Indonesia, University of Indonesia.

Sugiarta, A. A. G., 2008, Dampak Bising Dan Kualitas Udara Pada Lingkungan Kota Den Pasar, Jurusan Argo Sains Teknologi, Fakultas Pertanian, Universitas Udayana, Den Pasar.

Sukarto, H., 2006, Transportasi Perkotaan dan Lingkungan, Jurusan Teknik Sipil - Universitas Pelita Harapan, Banten.

Sukirman, S., 1994, Dasar-dasar Perencanaan Geometrik Jala, Nova, Bandung.

Wahyudi, E., 2002, Penanganan Persoalan Lalulintas Di Kawasan Perdagangan Secoyudan Surakarta, Departemen Teknik Planologi, Institut Teknologi Bandung.

Wardhana, Wisnu Arya, 2001, Dampak Pencemaran Lingkungan, Andi Offset, Yogyakarta.

Werdiningsih, Hermin, 2007, Kajian Penggunaan Tanaman sebagai Alternatif Pagar Rumah. ENCLOSURE : Volume 6 No. 1 Maret 2007, Jurnal Ilmiah Perancangan Kota dan Pemukiman. Didownload: http://eprints.undip.ac.id/18508/1/4.pdf. 